\title{
A SURVEY OF THE PATIENTS IN A LARGE MENTAL HOSPITAL
}

\author{
$\mathrm{BY}$
}

\author{
A. G. DUNCAN, L. S. PENROSE, AND R. C. TURNBULL, \\ Col.chester
}

\section{INTRODUGTION}

Althovgh, from the legal points of view, all individuals certified as of unsound mind have the same designation, every large mental institution contains a great variety of different types of patient, especially since the passing of the 1930 Mental Treatment Act. In Part I of the Annual Report of the Board of Control for 1933, for example, it was stated that at least $\mathbf{1 2 \cdot 2}$ per cent. of patients, certified under the Lunacy Acts, in general mental hospitals were mentally defective but not insane. As the years go by, an institutional population becomes saturated with chronic types, for many of the acute cases are discharged recovered. It is interesting and of some practical importance to know exactly what types of patients inhabit a mental hospital at a given time and how the resident population differs in composition from a sample of admissions. The present communication gives an account of a survey, the object of which was to obtain full information about the incidence, in Severalls Mental Hospital, of the various types of mentally disordered and mentally defective patients. Every resident patient was seen by the writers, and the records of each case were examined; a diagnosis of the type of mental disorder was made and also an estimate of the patient's initial mental capacity. Naturally, in some instances when the mental disorder had caused dementia, the estimate of the patient's initial mental capacity had to be made upon historical evidence rather than from direct examination.

While recognizing that, according to existing knowledge, any classification of mental disorders must be incomplete, the writers felt that the schedules 'Forms of Insanity' and 'Causes and Associated Factors of Insanity' in the Rules of the Commissioners in Lunacy could not offer a satisfactory basis for the proposed survey. The diagnosis recorded in the hospital registers is often made at a time too early in the observation of the patient to be accurate and complete. In many cases the restrictions of the Commissioners' Schedules actually compel the recording of a diagnosis known to be inaccurate. A frequent example of this is the case of a patient whose certification has been necessitated by symptoms of mental deficiency ' not amounting to imbecility '; the medical officer must then either register the patient as an imbecile, or 
allow his imagination to read into the instability associated with feeblemindedness a psychosis which he knows is not present. This is, perhaps, not the place to suggest a revision of the Commissioners' Schedules ; it was clear, however, to the writers at the outset that they could not be used as the foundation of a statistical survey. It was necessary, therefore, to develop a simple method of cross-classification of mental disorder and defect.

In respect of the diagnosis of mental disorder, the patients were grouped under five main headings: (i) schizophrenia, which included dementia simplex, dementia præcox, dementia paranoides, paraphrenia and paranoia ; (ii) organic insanities, which included general paralysis, toxic and traumatic states, involutional depressive, delusional and manic states, and senile dementia ; (iii) manic-depressive insanity; (iv) epileptic psychosis ; (v) cases without definite psychotic symptoms, a group which included neurosis, psychoneurosis, emotional instability, and mental defect uncomplicated by mental disorder.

Mental capacity was partly rated on the patient's ability to answer a few standardized questions, taken from Burt's Mental and Scholastic Tests, of which the reading tests were found to be the most useful. The patient's past history and, in particular, the school record were also taken into consideration. Until recently, in many schools, the mental grade and the school standard were closely correlated. Any patients now over the age of about 25 who had not reached Standard $V$ on leaving school at the age of 14 and any patients who were judged to have been incapable of reaching a mental age above nine or ten years were classed as mentally defective. Six categories of mental ability were chosen : (i) superior ; (ii) normal ; (iii) dull ; (iv) feebleminded (mental age of seven to nine or ten years); (v) imbecile (mental age of three to seven years); (vi) idiot (mental age below three years). The category of dullness included many patients who could not be said to be certifiably defective, but who were, nevertheless, subnormal. On the whole,

TABLE I

Patients in the Hospital (Resident Population), January, 1935

\begin{tabular}{|c|c|c|c|c|c|c|c|c|c|c|c|c|}
\hline \multirow{2}{*}{$\begin{array}{l}\text { Mental Grade } \\
\text { Superior }\end{array}$} & \multicolumn{2}{|c|}{ Schizophrenia } & \multicolumn{2}{|c|}{ Organic } & \multicolumn{2}{|c|}{$\begin{array}{c}\text { Manic- } \\
\text { depressive }\end{array}$} & \multicolumn{2}{|c|}{ Epilepsy } & \multicolumn{2}{|c|}{$\begin{array}{c}\text { No } \\
\text { psychosis }\end{array}$} & \multicolumn{2}{|c|}{ Totals } \\
\hline & $\begin{array}{r}\text { M. } \\
6\end{array}$ & F. & $\underset{5}{\mathbf{5}}$ & F. 5 & M. & F. & M. & $\mathbf{F}_{\mathbf{i}}$ & M. & F. & $\begin{array}{l}\text { M. } \\
15\end{array}$ & F. \\
\hline Normal & 252 & 441 & 135 & 211 & 44 & 107 & 21 & 16 & $\mathbf{1}$ & $\mathbf{3}$ & 453 & 778 \\
\hline Dull . & 143 & 164 & 40 & 45 & 27 & 36 & 16 & 10 & 6 & 3 & 232 & 258 \\
\hline Feebleminded & 57 & 58 & 6 & 11 & 26 & 38 & 15 & 17 & 23 & 28 & 127 & 152 \\
\hline Imbecile & 2 & 5 & 1 & - & 1 & $\mathbf{5}$ & 12 & 6 & 29 & 25 & 45 & 41 \\
\hline Idiot . & - & - & - & - & - & - & - & 2 & 8 & 4 & 8 & 6 \\
\hline Total & 460 & 680 & 187 & 272 & 100 & 187 & 66 & 52 & 67 & 63 & 880 & ,254 \\
\hline
\end{tabular}


the estimate of mental deficiency was cautiously made and many patients in whom feeblemindedness was suspected, but in whom it could not be definitely proved to exist, were given the benefit of the doubt and counted as dull or as normal.

\section{GENERAL RESULTS}

The total population of the hospital was 2,134 patients, of whom 880 were males and 1,254 females. The results of the classification of these patients are summarized in Tables I to VI. Some general deductions from these figures will first be considered. Taking Table I, in both sexes, together, the percentages of patients who fell into the different categories were as follows :-

\begin{tabular}{|c|c|c|c|c|c|c|}
\hline Type of Disorder & & & & & & Percentage \\
\hline Schizophrenia & - & . & - & , & • & . $\quad \mathbf{5 3 \cdot 4}$ \\
\hline Organic $\quad$. & . & . & . & . & . & $21 \cdot 5$ \\
\hline Manic-depressive & - & . & . & . & - & $13 \cdot 4$ \\
\hline Epilepsy & - & - & - & . & - & $5 \cdot 5$ \\
\hline No psychosis & . & . & • & & - & $6 \cdot 1$ \\
\hline Mental Grade & & & & & & Percentage \\
\hline Superior & - & . & • & . & - & . $\quad 1 \cdot 6$ \\
\hline Normal & - & . & • & - & - & $57 \cdot 7$ \\
\hline Dull . & • & - & & - & • & $23 \cdot 0$ \\
\hline Feebleminded & - & . & & . & . & $13 \cdot 1$ \\
\hline Imbecile & - & . & & . & . & $4 \cdot 0$ \\
\hline Idiot & . & . & & & . & $0 \cdot 7$ \\
\hline
\end{tabular}

Perhaps the most striking fact which emerges from these figures is the high incidence of mental subnormality. The total number of mentally subnormal patients is 869 , or 40.8 per cent., of whom 412 are males and 457 females. There were 180 males and 199 females, that is $17 \cdot 8$ per cent. of all patients, who could have been certified under the Mental Deficiency Acts. No psychosis was diagnosed in 130 cases (67 males and 63 females) and of such patients the great majority (60 males and 57 females) were mentally defective; cases of deficiency uncomplicated by mental disorder numbered 70 (40 males and 30 females). The proportions of mentally subnormal patients, in the various psychiatrical divisions, were as follows :-

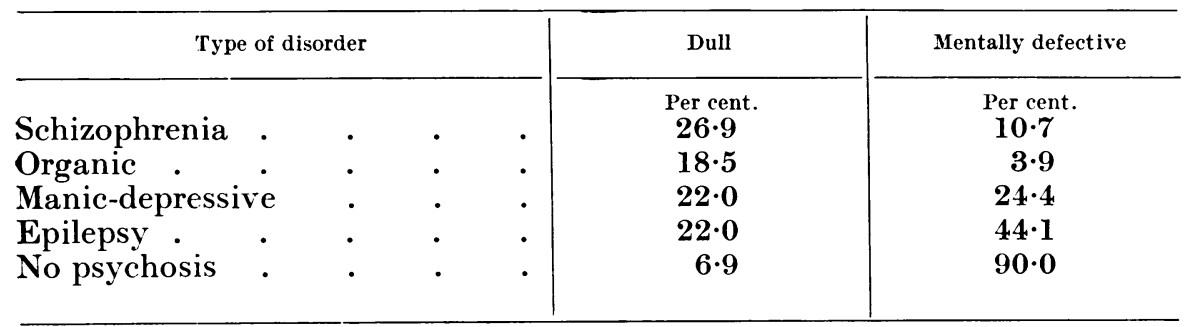

In the whole population females predominate over males, but there are relatively more male than female defectives : a similar relative excess of 
males (in a lesser degree) applies to patients diagnosed as mentally dull. Consequently in those types of mental disorder, such as epilepsy, which are closely associated with mental deficiency, there is a slight relative excess of males. Schizophrenia, the organic psychoses and manic-depressive insanity all show, in a like degree, an excess of females.

A detailed analysis of the incidence of different types of schizophrenia revealed that the paranoid types were much more common among females than among males; the paranoid psychoses seemed also to develop with greater frequency in individuals of normal than in those of weak intellect. These points are readily shown by the following figures.

\begin{tabular}{|c|c|c|c|c|}
\hline & Number & Females & Dull & $\begin{array}{l}\text { Mentally } \\
\text { defective }\end{array}$ \\
\hline $\begin{array}{l}\text { Paranoia : } \\
\text { Paraphrenia } \cdot \\
\text { Dementia paranoides } . \\
\text { Dementia præcox (all other } \\
\text { forms). }\end{array}$ & $\begin{array}{r}38 \\
256 \\
836\end{array}$ & $\begin{array}{l}\text { Per cent. } \\
79 \\
72 \\
55\end{array}$ & $\begin{array}{c}\text { Per cent. } \\
11 \\
22 \\
18\end{array}$ & $\begin{array}{c}\text { Per cent. } \\
5 \\
5\end{array}$ \\
\hline
\end{tabular}

An analysis of manic-depressive insanity showed that the symptoms varied with the patient's mental grade. Besides discovering the numerical association between mental defect and type of psychosis, this survey also suggested that the actual symptoms of a psychosis may be determined by the mental grade. For example, hallucinations, especially visual, in manicdepressive insanity are much more common in the lower mental grades.

Although mental subnormality is not infrequently associated with typical manic-depressive insanity, more often the manifestations of mania or depression in defective patients are of such short duration that they have to be regarded as signs of emotional instability rather than of insanity. The following figures show the proportions of manic-depressive and mentally unstable patients who are dull or defective.

TABLE II

1934 Admissions

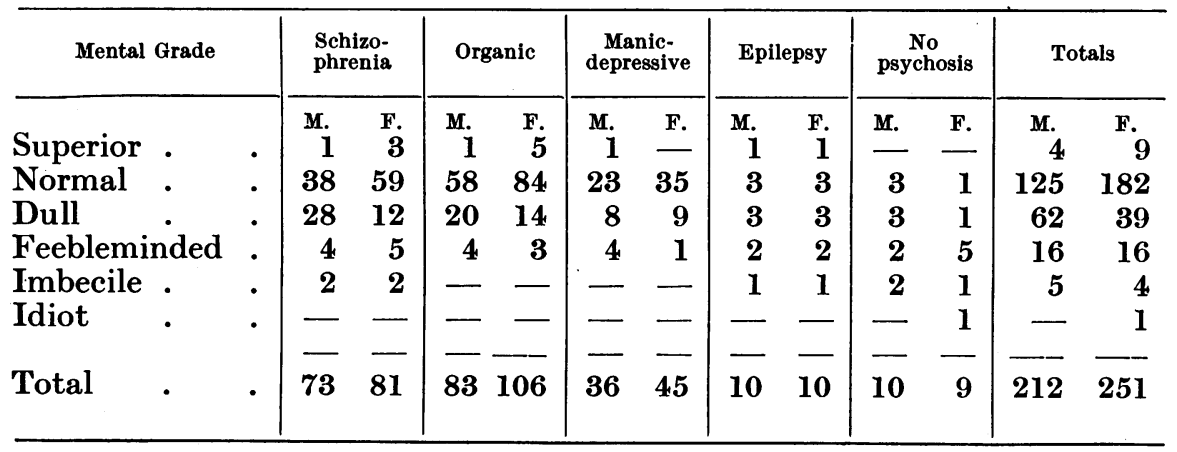




\begin{tabular}{|c|c|c|c|}
\hline & Number & Lull & $\begin{array}{l}\text { Mentally } \\
\text { defective }\end{array}$ \\
\hline Typical manic-depressive insanity & 272 & $\begin{array}{c}\text { Per cent. } \\
\mathbf{2 2}\end{array}$ & $\begin{array}{l}\text { Per cent. } \\
21\end{array}$ \\
\hline Mild forms of manic-depressive insanity & 15 & 13 & 80 \\
\hline Emotional instability . & 52 & 12 & 87 \\
\hline
\end{tabular}

\section{GOMPARISON OF RESIDENT POPULATION WITH ADMISSIONS}

In order to investigate further the significance of the different sizes of the specified groupings in Table $I$, the resident population was compared with the entering population. The sample of the entering population which was chosen comprised the 463 admissions during one year (1934) (see Table II). These patients were classified in the specified way according to type of mental disorder and grade. The following figures show how they compare with the resident population.

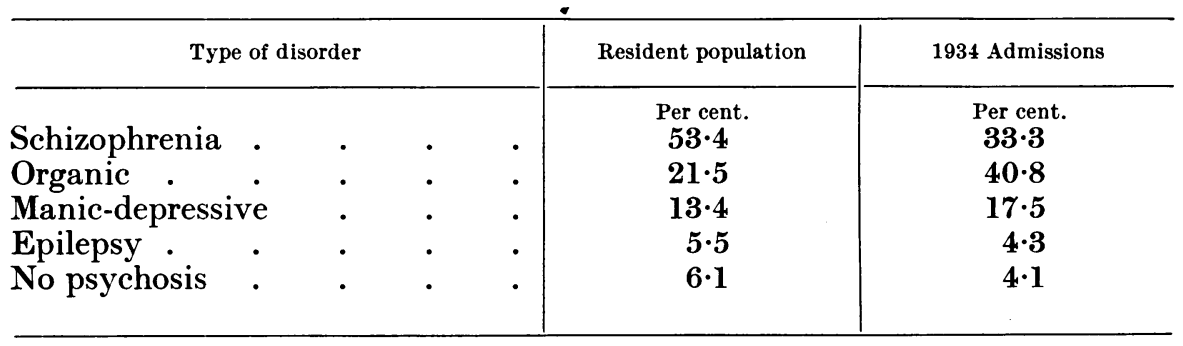

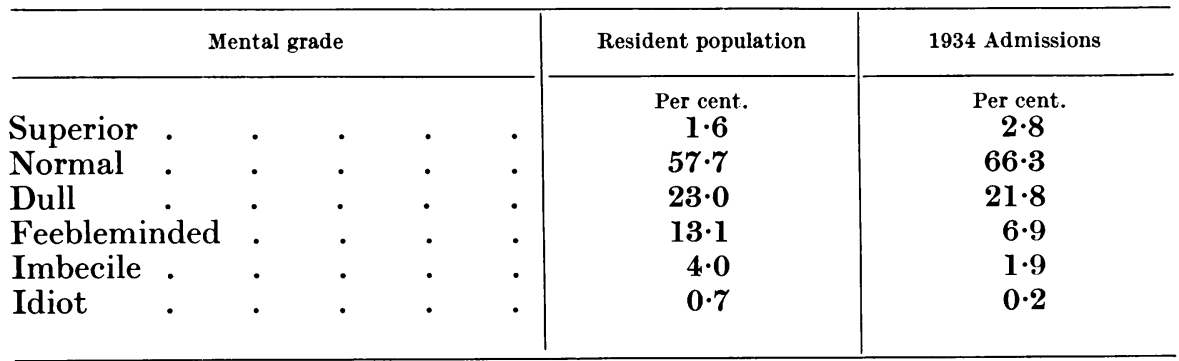

In comparing these figures, it must be remembered that a diagnosis made during the first year after admission may be inaccurate. Cases diagnosed as manic-depressive or confusional may afterwards develop symptoms which necessitate their inclusion in the schizophrenic group; a case may even be admitted and discharged as manic-depressive and yet be subsequently admitted as schizophrenic. It is seen that, though the schizophrenics form the largest class in the resident population, among the admissions they are fewer in number than the organic cases. The manic-depressive cases are, proportionately, nearly as frequent among the resident population as among admissions, probably because, although many recover temporarily, they have 
a strong tendency to relapse. The epileptics and those showing no definite psychosis have a greater frequency in the resident population than among the admissions, chiefly because they contain such a large number of mentally defective individuals. This point is further illustrated in the comparison of proportions of different mental grades in the admissions and in the resident population. The likelihood of an individual's remaining in the hospital is high if the mental grade on admission is found to be low.

The total number of patients admitted who were found to be mentally subnormal was 143, of whom 42 were certifiably defective. As in the resident group, a large proportion who had no definite psychosis were defective, i.e. 11 out of 19. The proportion of epileptics admitted who were defective was also high-six out of 20 . On the other hand, the relatively high proportion of manic-depressives judged to be defective in the resident group. was not shown among the admissions ; only five were found out of 81 . Of those admitted suffering from organic insanity, only seven out of 189 were judged to be mentally defective : this psychiatric group therefore had, among admissions as in the resident population, the highest average mental grade. The schizophrenics admitted contained 13 defectives out of 154 cases; the proportion, 8.4 per cent., is practically the same as the proportion among manic-depressive admissions and agrees with the proportion found in the resident population of schizophrenics. The comparison of the admissions with the resident population enables us to say with some degree of assurance that mental subnormality and deficiency are least prominent in the organic insanities, and that 9 or 10 per cent. of schizophrenics and a much higher proportion of epileptics are mentally defective. The difficulty in distinguishing between true manic-depressive insanity and the symptoms of emotional instability shown by feebleminded individuals throws some doubt on the apparent association between manic-depressive insanity and mental deficiency. Nevertheless, it appears that this association is fairly marked, and that, next to epilepsy, the manic-depressive type of reaction is the commonest psychosis among the mentally defective.

TABLE IIIA

Resident Population Analysed According to Length of Time Since Admission

\begin{tabular}{|c|c|c|c|c|c|c|c|}
\hline Type of disord & der & & $0-5$ years & $5-10$ years & $10-15$ years & $15-20$ years & 20 years + \\
\hline Schizophrenia & . & - & $\begin{array}{l}\text { Per cent. } \\
\mathbf{4 5 \cdot 3}\end{array}$ & $\begin{array}{c}\text { Per cent. } \\
53.5\end{array}$ & $\begin{array}{c}\text { Per cent. } \\
55 \cdot 0\end{array}$ & $\begin{array}{c}\text { Per cent. } \\
57 \cdot 4\end{array}$ & $\begin{array}{c}\text { Per cent. } \\
69 \cdot 8\end{array}$ \\
\hline Organic . & . & . & $\mathbf{3 2 \cdot 3}$ & $23 \cdot 4$ & $12 \cdot 9$ & $8 \cdot 8$ & $8 \cdot 0$ \\
\hline Manic-depressiv & & . & $14 \cdot 8$ & $13 \cdot 6$ & $16 \cdot 2$ & $13 \cdot 9$ & $7 \cdot 4$ \\
\hline Epileptic & . & . & $4 \cdot 6$ & 6.9 & $6 \cdot 8$ & $11 \cdot 1$ & $2 \cdot 2$ \\
\hline No psychosis & - & . & $3 \cdot 1$ & $2 \cdot 6$ & $9 \cdot 1$ & $8 \cdot 8$ & $12 \cdot 6$ \\
\hline Total number & - & . & 899 & 346 & 309 & 216 & 364 \\
\hline
\end{tabular}




\section{TABLE IIIB}

Resident Population Analysed According to Length of Time Since Admission

\begin{tabular}{|c|c|c|c|c|c|c|c|}
\hline \multicolumn{3}{|c|}{ Mental grade } & $0-5$ years & $5-10$ years & $10-15$ years & $15-20$ years & 20 years + \\
\hline Superior & . & . & $\begin{array}{c}\text { Per cent. } \\
2 \cdot 6\end{array}$ & $\begin{array}{c}\text { Per cent. } \\
0.9\end{array}$ & $\begin{array}{c}\text { Per cent. } \\
\mathbf{l} \cdot \mathbf{0}\end{array}$ & $\begin{array}{c}\text { Per cent. } \\
\mathbf{1} \cdot \mathbf{4}\end{array}$ & $\begin{array}{c}\text { Per cent. } \\
0.5\end{array}$ \\
\hline Normal & . & . & $61 \cdot 3$ & $59 \cdot 5$ & $52 \cdot 8$ & $48 \cdot 6$ & $56 \cdot 6$ \\
\hline Dull & . & . & $24 \cdot 2$ & $22 \cdot 8$ & $23 \cdot 6$ & $25 \cdot 9$ & $17 \cdot 6$ \\
\hline Feebleminded & . & . & $9 \cdot 5$ & $13 \cdot 3$ & $17 \cdot 2$ & $17 \cdot 6$ & $15 \cdot 7$ \\
\hline Imbecile . & . & . & $1 \cdot 9$ & $3 \cdot 2$ & $3 \cdot 6$ & $6 \cdot 5$ & $9 \cdot 1$ \\
\hline Idiot & . & . & $0 \cdot 6$ & $0 \cdot 3$ & $1 \cdot 9$ & 一 & 0.5 \\
\hline Total number & • & . & 899 & 346 & 309 & 216 & 364 \\
\hline
\end{tabular}

Further information concerning the subsequent history of patients of different types and grades, who enter the mental hospital, can be gleaned from the more detailed analysis of the resident population which is given in Tables IIIA and ІІІв. The proportion of schizophrenics steadily rises in any sample of patients as the length of time of residence increases, whilst the proportion of organic cases falls off rapidly. Setting aside the group of chronic non-psychotics who are mostly mentally defective, few patients other than schizophrenics stay in the hospital more than 20 years. The proportion of patients of normal intelligence decreases with length of time of residence up to more than 15 years; but the patients admitted more than 20 years ago appear to include a larger proportion again ( $56 \cdot 6$ per cent.) of those of the normal grade. Possibly too many of the patients who had been in the hospital for this long period were rated as normal owing to incomplete histories. Patients of the idiot grade scarcely figure in the groups resident in the hospital for over 15 years, but the duration of residence of many imbeciles has been very long. It must be remembered, when examining these figures, that the operation of the Mental Deficiency Acts has become increasingly effective and fewer imbeciles are admitted now per year than 20 years ago.

Apart from administrative considerations, the differences between the composition of the specified groups in the entering and resident populations are determined by the powers of recovery and the life expectation of the patients admitted. Table IV shows what happens to the admissions of various types and grades. The schizophrenics are, on the whole, young on admission and few are discharged. Conversely, the organic cases are mostly elderly on admission and many of them succumb to illness. The manicdepressives show much the highest discharge rate of any group. Where mental grade is concerned, it is fairly clear that the silting up of dull and defective patients in the residue is caused partly by reason of their good health and partly by reason of the low rate of their discharge. 
Table IV

1934 Admissions

\begin{tabular}{|c|c|c|c|c|c|}
\hline \multirow{2}{*}{\multicolumn{3}{|c|}{ Type of disorder }} & \multirow{2}{*}{$\begin{array}{l}\text { Mean age in years } \\
\text { on admission }\end{array}$} & \multicolumn{2}{|c|}{$\begin{array}{c}\text { (Mean length of time of residence in } \\
\text { hospital-six months) }\end{array}$} \\
\hline & & & & Discharged & Died in 1934 \\
\hline $\begin{array}{l}\text { Schizophrenia } \\
\text { Organic } \\
\text { Manic-depressive } \\
\text { Epileptic } \\
\text { No psychosis . }\end{array}$ & $\begin{array}{l}\cdot \\
\bullet \\
\bullet\end{array}$ & $\begin{array}{l}\cdot \\
\cdot \\
\cdot\end{array}$ & $\begin{array}{l}31 \cdot 7 \\
54 \cdot 5 \\
47 \cdot 2 \\
33 \cdot 4 \\
35 \cdot 5\end{array}$ & $\begin{array}{l}\text { Per cent. } \\
21 \\
14 \\
40 \\
20 \\
42\end{array}$ & $\begin{array}{c}\text { Per cent. } \\
3 \\
19 \\
6 \\
5 \\
5\end{array}$ \\
\hline \multirow{2}{*}{ Mental grade } & & & \multirow{2}{*}{$\begin{array}{l}\text { Mean age in years } \\
\text { on admission }\end{array}$} & \multicolumn{2}{|c|}{$\begin{array}{l}\text { (Mean length of time of residence in } \\
\text { hospital-six months) }\end{array}$} \\
\hline & & & & Discharged & Died in 1934 \\
\hline $\begin{array}{l}\text { Superior } \\
\text { Normal . } \\
\text { Dull } \\
\text { Feebleminded } \\
\text { Imbecile } \\
\text { Idiot . }\end{array}$ & $\begin{array}{l}\cdot \\
\text { • } \\
\text {. }\end{array}$ & $\begin{array}{l}\cdot \\
\bullet \\
\bullet\end{array}$ & $\begin{array}{l}40 \cdot 3 \\
46 \cdot 0 \\
40 \cdot 7 \\
38 \cdot 0 \\
37 \cdot 8 \\
37 \cdot 0\end{array}$ & $\begin{array}{c}\text { Per cent. } \\
25 \\
43 \\
21 \\
22 \\
11 \\
0\end{array}$ & $\begin{array}{c}\text { Per cent. } \\
0 \\
15 \\
5 \\
6 \\
0 \\
0\end{array}$ \\
\hline
\end{tabular}

\section{PHYSICAL MEASUREMENTS}

As far as was practicable, in the course of the survey which is here reported upon, each patient's stature was noted and the head length and breadth were measured. Patients below the age of 19 years were excluded from this part of the investigation. Table $\mathrm{V}$ records the mean heights of patients classified according to type of disorder and mental grade. Males and females had to be considered separately. The average heights in schizophrenia, organic psychosis and manic-depressive insanity are reasonably similar to one another, but the non-psychotic are definitely shorter in stature. This difference is likely to be due to the presence, among the non-psychotic group, of a large number of patients of low grade mentality who are, on the average, considerably shorter than those of normal mentality. Both the male and the female average statures are closely associated with degree of intelligence, and the regularity of this association is quite surprising. This correlation of stature with mental grade was also evident for any given type of mental disorder. Our figures here can be used to test whether schizophrenics, who are supposed, by Kretschmer, to be predominantly tall and thin, have greater stature than manic-depressives, who are said to tend to be short and fat, and we find no evidence that this view is correct. 
Table V

\begin{tabular}{|c|c|c|c|c|c|c|}
\hline \multirow{2}{*}{\multicolumn{3}{|c|}{ Type of disorder }} & \multicolumn{2}{|r|}{ Males } & \multicolumn{2}{|r|}{ Females } \\
\hline & & & $\begin{array}{l}\text { No. of } \\
\text { cases }\end{array}$ & Average height & $\begin{array}{l}\text { No. of } \\
\text { cases }\end{array}$ & A verage height * \\
\hline $\begin{array}{l}\text { Schizophrenia } \\
\text { Organic } \\
\text { Manic-depressive } \\
\text { Epilepsy } \\
\text { No psychosis }\end{array}$ & • & $\begin{array}{l}\dot{ } \\
\dot{ } \\
\dot{ } \\
\dot{ }\end{array}$ & $\begin{array}{r}441 \\
177 \\
96 \\
61 \\
56\end{array}$ & $\begin{array}{l}5 \mathrm{ft} .6 \cdot 1 \text { in. } \\
5 \mathrm{ft} .5 \cdot 5 \mathrm{in} . \\
5 \mathrm{ft} .6 \cdot 3 \mathrm{in} . \\
5 \mathrm{ft} .5 \cdot 5 \mathrm{in} . \\
5 \mathrm{ft} .4 \cdot 9 \mathrm{in} .\end{array}$ & $\begin{array}{r}626 \\
258 \\
179 \\
46 \\
54\end{array}$ & $\begin{array}{l}5 \mathrm{ft} .1 \cdot 8 \mathrm{in.} \\
5 \mathrm{ft} .1 \cdot 2 \mathrm{in} . \\
5 \mathrm{ft} .1 \cdot 0 \mathrm{in.} \\
5 \mathrm{ft} .1 \cdot 1 \mathrm{in.} \\
4 \mathrm{ft} .11 \cdot 6 \mathrm{in} .\end{array}$ \\
\hline \multirow{2}{*}{ Mental grade } & & & \multicolumn{2}{|r|}{ Males } & \multicolumn{2}{|r|}{ Females } \\
\hline & & & $\begin{array}{l}\text { No. of } \\
\text { cases }\end{array}$ & Average height & $\begin{array}{l}\text { No. of } \\
\text { cases }\end{array}$ & Average height \\
\hline $\begin{array}{l}\text { Superior } \\
\text { Normal } \\
\text { Dull } \\
\text { Feebleminded } \\
\text { Imbecile } \\
\text { Idiot . }\end{array}$ & $\begin{array}{l}\dot{ } \\
\dot{.} \\
\dot{ } \\
\dot{ } \\
.\end{array}$ & $\begin{array}{l}\dot{.} \\
\dot{.} \\
\dot{.}\end{array}$ & $\begin{array}{r}15 \\
436 \\
220 \\
117 \\
40 \\
3\end{array}$ & $\begin{array}{l}5 \mathrm{ft} .6 \cdot 6 \mathrm{in} . \\
5 \mathrm{ft} .6 \cdot 1 \mathrm{in} . \\
5 \mathrm{ft} .5 \cdot 9 \mathrm{in} . \\
5 \mathrm{ft} .5 \cdot 6 \mathrm{in.} \\
5 \mathrm{ft} .4 \cdot 0 \mathrm{in} . \\
5 \mathrm{ft} .4 \cdot 3 \mathrm{in} .\end{array}$ & $\begin{array}{r}18 \\
735 \\
235 \\
135 \\
35 \\
5\end{array}$ & $\begin{array}{l}5 \mathrm{ft} . \quad 3 \cdot 7 \mathrm{in} . \\
5 \mathrm{ft} .1 \cdot 7 \mathrm{in} . \\
5 \mathrm{ft} .1 \cdot 3 \mathrm{in} . \\
5 \mathrm{ft} .0 \cdot 4 \mathrm{in} . \\
4 \mathrm{ft} .11 \cdot 2 \mathrm{in} . \\
4 \mathrm{ft} .7 \cdot 1 \mathrm{in} .\end{array}$ \\
\hline
\end{tabular}

* The standard deviation of female stature is $2 \cdot 76$ in., and that of male stature $2 \cdot 77$ in.

It has been pointed out by many workers that there is a certain degree of association between size and mental ability.1, 2 The mean stature for the total institutional population here is significantly below the average height for English people. If, however, we take merely those of normal ability, the diminution is slight. There is difficulty in knowing exactly what is the mean stature of normal members of the community : generally accepted figures are 5 feet $7 \frac{1}{2}$ inches for Englishmen and about 5 feet $2 \frac{1}{2}$ inches for Englishwomen.

Head measurements were taken in a large number of cases, and the results of this inquiry were very similar to those of the measurements of stature. Head size, however, is subject to certain variations which are liable to make averages unsatisfactory. There were two hydrocephalic male idiots, and the inclusion of their measurements tended to make the average head length and breadth for male idiots somewhat unusually large. The means for males and females, according to type of disorder and mental grade, are given in Table VI. It is fairly evident from these figures that mental grade is a factor of more importance here than type of disorder. There is little variation between the mean head measurements in different psychiatric groups and that which exists can be attributed to the differing compositions of these groups in respect of mental grade. Head size does not appear to be affected 
TABLE VI

\begin{tabular}{|c|c|c|c|c|c|c|c|c|}
\hline \multirow{2}{*}{\multicolumn{2}{|c|}{ Type of disorder }} & & \multicolumn{3}{|c|}{ Males } & \multicolumn{3}{|c|}{ Females } \\
\hline & & & $\begin{array}{l}\text { No. of } \\
\text { cases }\end{array}$ & $\begin{array}{c}\text { Average } \\
\text { head } \\
\text { length }\end{array}$ & $\begin{array}{l}\text { Average } \\
\text { head } \\
\text { breadth }\end{array}$ & $\begin{array}{l}\text { No. of } \\
\text { cases }\end{array}$ & $\begin{array}{c}\text { Average } \\
\text { head } \\
\text { length }\end{array}$ & $\begin{array}{c}\text { Average } \\
\text { head } \\
\text { breadth }\end{array}$ \\
\hline $\begin{array}{l}\text { Schizophrenia } \\
\text { Organic } \\
\text { Manic-depressive } \\
\text { Epilepsy } \\
\text { No psychosis }\end{array}$ & $\begin{array}{l}\dot{ } \\
\dot{ } \\
\dot{ } \\
\dot{ } \\
\dot{ }\end{array}$ & $\begin{array}{l}\cdot \\
\cdot \\
\cdot \\
\cdot \\
\cdot\end{array}$ & $\begin{array}{r}379 \\
124 \\
71 \\
50 \\
58\end{array}$ & $\begin{array}{l}195 \\
195 \\
193 \\
193 \\
192\end{array}$ & $\begin{array}{l}151 \\
151 \\
151 \\
151 \\
149\end{array}$ & $\begin{array}{r}517 \\
168 \\
140 \\
49 \\
52\end{array}$ & $\begin{array}{l}184 \\
185 \\
185 \\
182 \\
181\end{array}$ & $\begin{array}{l}145 \\
146 \\
145 \\
142 \\
144\end{array}$ \\
\hline \multirow{2}{*}{\multicolumn{3}{|c|}{ Mental grade }} & \multicolumn{3}{|c|}{ Males } & \multicolumn{3}{|c|}{ Females } \\
\hline & & & $\begin{array}{l}\text { No. of } \\
\text { cases }\end{array}$ & $\begin{array}{l}\text { Average } \\
\text { head } \\
\text { length }\end{array}$ & $\begin{array}{l}\text { Average } \\
\text { head } \\
\text { breadth }\end{array}$ & $\begin{array}{l}\text { No. of } \\
\text { cases }\end{array}$ & $\begin{array}{l}\text { Average } \\
\text { head } \\
\text { length }\end{array}$ & $\begin{array}{l}\text { Averag } \\
\text { head } \\
\text { breadth }\end{array}$ \\
\hline Superior & • & & 14 & 196 & 152 & 14 & 183 & 146 \\
\hline Normal & • & & 339 & 195 & 152 & 553 & 185 & 145 \\
\hline Dull . & & & 175 & 194 & 151 & 196 & 185 & 145 \\
\hline Feebleminded & . & . & 109 & 193 & 150 & 120 & 182 & 144 \\
\hline Imbecile . & $\bullet^{\circ}$ & . & 37 & 190 & 148 & 37 & 179 & 141 \\
\hline Idiot . & • & . & 8 & 194 & 152 & 6 & 178 & 139 \\
\hline
\end{tabular}

to any great extent by nutrition; the mean head size can therefore be regarded as an accurate index of constitutional physique. The average head length and head breadth for adult males and females in Australia have been measured with the following result :-

\begin{tabular}{|c|c|c|c|}
\hline \multicolumn{4}{|c|}{ Head Size (Australians, Melbourne) ${ }^{3}$} \\
\hline Head length & Head breadth & Head length ${ }^{\mathrm{N}}$ & Head breadth \\
\hline 194 & 153 & 185 & 146 \\
\hline
\end{tabular}

These averages do not differ significantly from those found for our patients of normal mental ability. Several investigators have reported that head size and stature are abnormally small in mental hospital populations. 4 From our figures it appears that such results may have been due to the inclusion in the sample of a large proportion of defectives.

\section{STIGMATA}

The male patients were examined for the presence and absence of certain stigmata of degeneration, namely, abnormal palate, skeletal deformity and post-anal dimple. The proportion of abnormal palates found among males was 12.31 per cent. The following figures show the incidence of abnormal palates among resident patients belonging to the different specified groups. 
Incidence of Abnormal Palate (Males)

\begin{tabular}{|c|c|c|c|c|}
\hline \multicolumn{3}{|c|}{ Type of disorder } & Number & Percentage \\
\hline $\begin{array}{l}\text { Schizophrenia } \\
\text { Organic . } \\
\text { Manic-depressive } \\
\text { Epilepsy • } \\
\text { No psychosis . }\end{array}$ & $\begin{array}{l}\dot{.} \\
\dot{.} \\
\dot{.}\end{array}$ & $\begin{array}{ll}\cdot & \cdot \\
\cdot & \cdot \\
\cdot & \cdot \\
\cdot & \cdot \\
\cdot & \cdot\end{array}$ & $\begin{array}{r}52 \\
15 \\
9 \\
17 \\
15\end{array}$ & $\begin{array}{r}11 \cdot 4 \\
8 \cdot 1 \\
9 \cdot 0 \\
25 \cdot 8 \\
22 \cdot 4\end{array}$ \\
\hline \multicolumn{3}{|c|}{ Mental grade } & Number & Percentage \\
\hline $\begin{array}{ll}\text { Superior } & \text {. } \\
\text { Normal } & \text {. } \\
\text { Dull } & \text {. } \\
\text { Feebleminded } & \text {. } \\
\text { Imbecile . } & \text {. } \\
\text { Idiot } & \text {. }\end{array}$ & $\begin{array}{l}\dot{.} \\
\dot{.} \\
\dot{.}\end{array}$ & $\begin{array}{ll}\cdot & . ! \\
\cdot & . j \\
. & . \\
. & . \\
\cdot & . ! \\
. & . j\end{array}$ & $\begin{array}{l}44 \\
22 \\
26 \\
16\end{array}$ & $\begin{array}{r}9 \cdot 4 \\
9 \cdot 6 \\
20 \cdot 5 \\
30 \cdot 2\end{array}$ \\
\hline
\end{tabular}

Under the type of disorder grouping it is noticeable that about onequarter of epileptics and non-psychotics have abnormally narrow palates. Between the schizophrenics, organic cases and manic-depressives there is not very much difference: these types all show a lower incidence. On the other hand, there is a marked association between abnormal palate and mental subnormality, as can be seen from examination of the figures in the mental grade grouping. The high proportion of epileptics and non-psychotics who have this abnormality is thus to be expected.

Patients of low mental grade exhibited skeletal abnormalities frequently; hence a high incidence among epileptics and non-psychotics was again to be expected. The following figures show the incidence of skeletal abnormalities in the different groupings.

Incidence of Skeletal Abnormalities (Males)

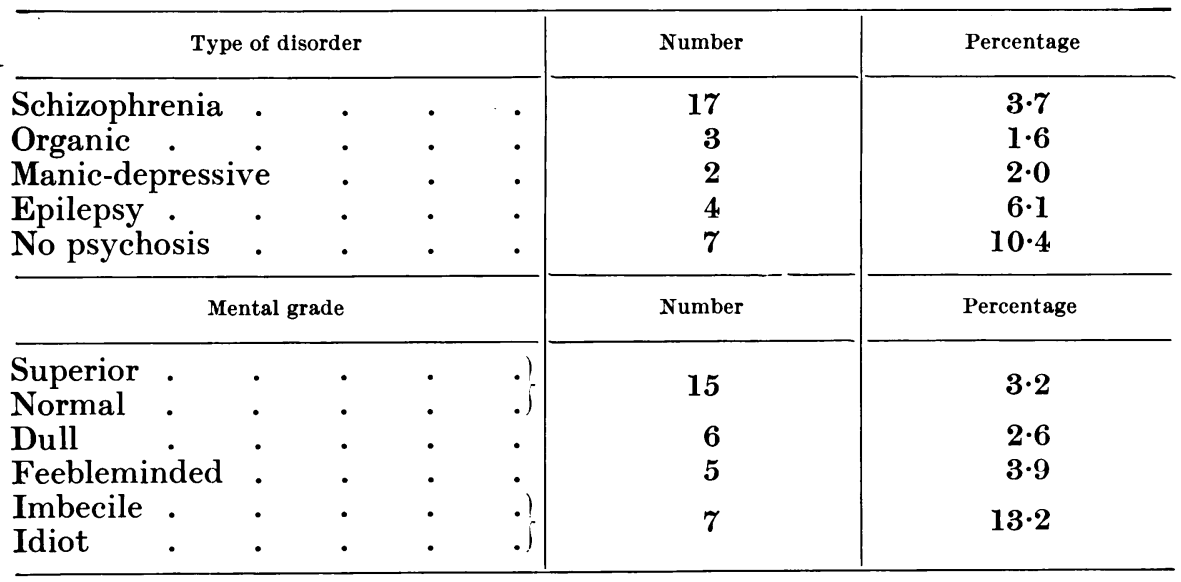


Skeletal abnormalities included cranial deformities (asymmetry of skull, hydrocephaly, acrocephaly, etc.) and deformities of the spine or limbs (scoliosis, kyphosis, spina bifida, syndactyly, club foot, etc.).

A post-anal dimple, marking the site of the posterior end of the primitive neural canal, is a normal surface marking. Sometimes, however, it is unusually deep, and it may even be represented by a narrow blind canal running upwards for $2 \mathrm{~cm}$. or more. Every male patient in the hospital had been examined, as a routine procedure, for hæmorrhoids and other anal abnormalities, and the presence or absence of a post-anal canal or pathological dimple was noted in every case. The following figures show the marked association of this stigma with epilepsy and with mental defect.

Incidence of Post-anal Dimple

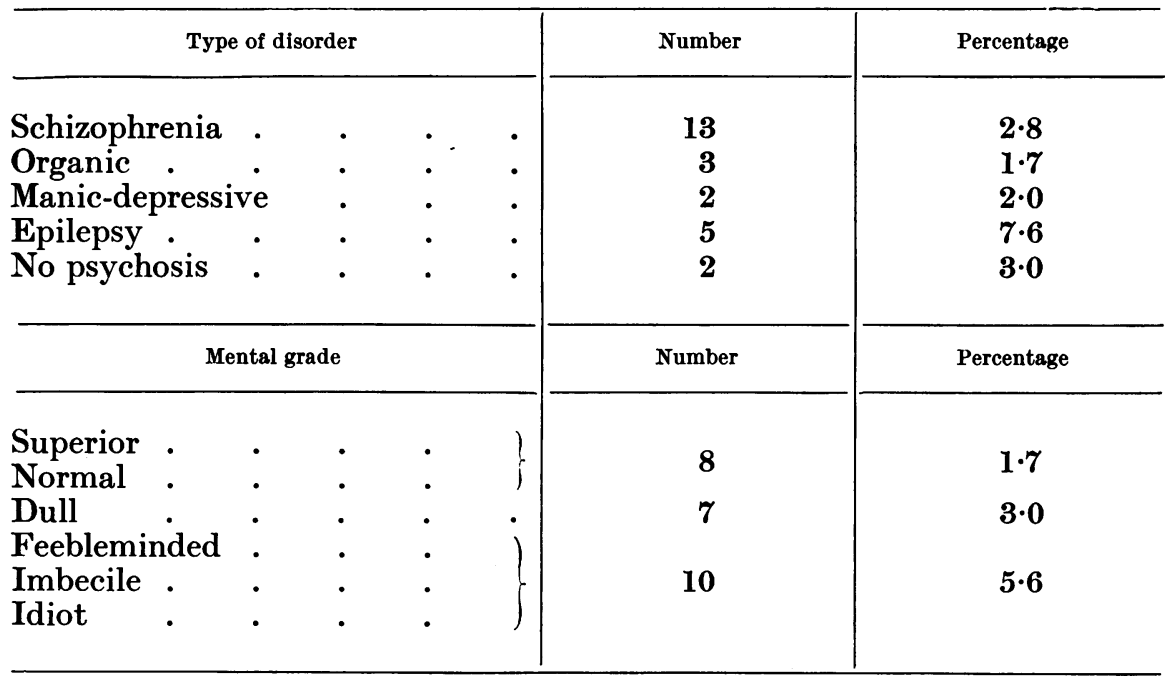

\section{FAMILIAL INGIDENGE}

Owing to the somewhat incomplete nature of the data on which the following figures are based, the absolute magnitudes of the various proportions recorded cannot be taken to have precise significance. The criteria on which the data are based were not fixed : when it is noted that a relative is affected it is not known whether the relative was mentally defective or whether he suffered from any special type of psychosis. The supposition is often made that the same kind of mental trouble is found in different members of the same family. Little evidence for this view has, however, been obtained from the examination of the pairs of brothers and sisters who are in the hospital. From the clinical point of view mental disease is not very true to type. For example, the known relatives of our manic-depressive patients were more frequently schizophrenic than manic-depressive. The following figures 
represent the numbers of patients' parents and sibs who showed some definite psychosis or mental defect. The type of disorder and mental grade of the patients is specified. The figures are given in the form of decimals, which show the number of near relatives affected per patient.

\section{Incidence of Mental Disease or Deficiency among near Relatives of Resident Patients}

\begin{tabular}{|c|c|c|c|c|}
\hline \multirow{2}{*}{ Type of disorder } & \multicolumn{2}{|c|}{ Parents } & \multicolumn{2}{|c|}{ Sibs } \\
\hline & $\begin{array}{l}\text { Number } \\
\text { affected }\end{array}$ & $\begin{array}{c}\text { Incidence per } \\
\text { patient }\end{array}$ & $\begin{array}{l}\text { Number } \\
\text { affected }\end{array}$ & $\begin{array}{c}\text { Incidence per } \\
\text { patient }\end{array}$ \\
\hline $\begin{array}{l}\text { Schizophrenia } \\
\text { Organic . } \\
\text { Manic-depressive. } \\
\text { Epilepsy } \\
\text { No psychosis } \\
\text { All classes . }\end{array}$ & $\begin{array}{r}154 \\
40 \\
52 \\
13 \\
18 \\
277\end{array}$ & $\begin{array}{l}0 \cdot 135 \\
0 \cdot 087 \\
0 \cdot 181 \\
0 \cdot 110 \\
0 \cdot 138 \\
0 \cdot 130\end{array}$ & $\begin{array}{r}217 \\
70 \\
94 \\
17 \\
16 \\
414\end{array}$ & $\begin{array}{l}0 \cdot 190 \\
0 \cdot 153 \\
0 \cdot 327 \\
0 \cdot 144 \\
0 \cdot 123 \\
0 \cdot 193\end{array}$ \\
\hline \multirow{2}{*}{ Mental grade } & \multicolumn{2}{|c|}{ Parents } & \multicolumn{2}{|c|}{ Sibs } \\
\hline & $\begin{array}{l}\text { Number } \\
\text { affected }\end{array}$ & $\begin{array}{c}\text { Incidence per } \\
\text { patient }\end{array}$ & $\begin{array}{l}\text { Number } \\
\text { affected }\end{array}$ & $\begin{array}{c}\text { Incidence per } \\
\text { patient }\end{array}$ \\
\hline $\begin{array}{ll}\text { Superior } & \cdot \\
\text { Normal } & \text {. } \\
\text { Dull . } & \text {. } \\
\text { Feebleminded } & \text {. } \\
\text { Imbecile . } & \text {. } \\
\text { Idiot . } & \text {. }\end{array}$ & $\begin{array}{r}5 \\
143 \\
71 \\
42 \\
13 \\
3\end{array}$ & $\begin{array}{l}0 \cdot 147 \\
0 \cdot 116 \\
0 \cdot 145 \\
0 \cdot 151 \\
0 \cdot 153 \\
0 \cdot 214\end{array}$ & $\begin{array}{r}8 \\
231 \\
107 \\
57 \\
11 \\
0\end{array}$ & $\begin{array}{l}0 \cdot 235 \\
0 \cdot 188 \\
0 \cdot 218 \\
0 \cdot 204 \\
0 \cdot 129 \\
0 \cdot 000\end{array}$ \\
\hline
\end{tabular}

In so far as the incidence of mental trouble in the near relatives of a patient is evidence of hereditary influence, such influence is clearly more important in manic-depressive insanity than in other clinical types. With epilepsy and the organic psychoses, hereditary predisposition is less marked. It is interesting to note that, among the $\mathbf{4 5 9}$ organic cases, there were $\mathbf{3 8}$ suffering from general paralysis. The incidence of mental disease recorded in the relatives of these $\mathbf{3 8}$ cases was of the same order as the incidence in other organic cases, i.e. $\mathbf{0 \cdot 1 4}$ for parents and $\mathbf{0 . 0 6}$ for sibs. It is well known that the feebleminded often have feebleminded relatives, though whether this signifies that heredity or environment is the more important ætiological factor is a matter still in dispute. In the present series of cases there is evidence that familial incidence of mental trouble is more marked when the mentality of the patient is low than when it is high; the differences between the groups are not, however, nearly as marked as in the case of manicdepressive insanity and organic psychosis. The significance of these figures 
in the diagnosis of heredity as a cause of insanity can only be appreciated by referring to estimates for the incidence of insanity and mental deficiency in the general population. The expectation of mental disease for any individual has been estimated by Luxemburger to be 0.044 : the estimate does not include mental defect. Schultz gave the figure of 0.066 for the total expectation of mental disease and mental defect. In New York State the chance that any male born is treated for mental disorder before his generation passes is 0.047.5 Apparently the incidence of mental disease and defect is from two to four times as great among the near relatives of patients as in the general community.

\section{SUMMARY}

An analysis has been made of the population under the care of a large mental hospital. The cases have been classified according to type of mental disorder and also according to mental grade. The incidence of mental defect was found to be $\mathbf{1 7 \cdot 8}$ per cent. and the incidence of mental dullness 23 per cent. The different types of psychoses showed different degrees of association with mental deficiency; manic-depressive insanity and epilepsy had the strongest association with low mentality.

The way in which the entering population became modified in the course of years was studied in respect of the different psychoses and mental grades.

Physical measurements and stigmata in the different groups were investigated, and it was demonstrated that physical abnormalities were more closely associated with low mental grade than with any special type of psychosis, if due allowance for intelligence of the groups was made. Some data bearing on the familial incidence of mental disorder were also analysed.

The writers are much indebted to Dr. N. Haworth for her help in carrying out the survey and to Miss H. Lang Brown for statistical work.

\section{REFERENCES}

${ }^{1}$ Goddard, H., Jour. Nerv. Ment. Dis., 1912, 39, 217.

2 Stewart, R. M., and Ashby, W. R., Jour. Neurol. and Psychopathol., 1933, 13, 303.

3 Berry, R. J. A., and Porteus, S. D., Intelligence and Social Valuation, 1920.

${ }^{4}$ Clegg, M. B., Jour. Ment. Sci., 1935, 81, 297. (This paper gives a useful list of references.)

s Pollock, H. M., Malzberg, B., and Fuller, R. G., Psychiatric Quarterly, Jan., 1935. 